\title{
Pengaruh Kepemimpinan Otentik Terhadap Perilaku Kewargaan Organisasional
}

\author{
Rizkita Cahya Henviana $^{1 *}$ dan Ma'mun Sutisna ${ }^{2}$ \\ ${ }^{1}$ Jurusan Administrasi Niaga, Politeknik Negeri Bandung, Indonesia \\ ${ }^{2}$ Jurusan Administrasi Niaga, Politeknik Negeri Bandung, Indonesia
}

\begin{abstract}
:
This study aims to determine the role of Authentic Leadership (AL) and Organizational Citizenship Behavior (OCB) also to analyze the relationship of these variables in Hypermart Bandung. This study consists of 4 dimension of AL (self awareness, relational transparency, internalized moral perspective, and balance processing) and 5 dimensions of OCB (altruism, civic virtue, conscientiousness, courtesy and sportsmanship). Research using linear regression and descriptive statistics. Data collection used questionnaire given to 150 employees of Hypermart Bandung. The results of this study indicate that the role of AL of the leader in Hypermart resulted in good category. Similarly, OCB on employees resulted in good category. It is also known that AL has a positive and significant effect on OCB. The level of $A L$ influence on $O C B$ is $23.7 \%$, while $76.3 \%$ is influenced by other factors not explained in this research.
\end{abstract}

Keywords: authentic leadership, leadership, organizational behavior, organizational citizenship behavior

\begin{abstract}
Abstrak:
Penelitian ini bertujuan untuk mengetahui peran Authentic Leadership (AL) dan Organizational Citizenship Behavior Behavior (OCB) juga untuk menganalisis pengaruh variabel-variabel ini di Hypermart Bandung. Penelitian ini terdiri dari 4 dimensi AL (kesadaran diri, transparansi relasional, perspektif moral yang diinternalisasi, dan pemrosesan keseimbangan) dan 5 dimensi OCB (altruisme, kebajikan kewarganegaraan, perhatian, sopan santun dan sportivitas). Penelitian menggunakan regresi linier dan statistik deskriptif. Pengumpulan data menggunakan kuesioner yang diberikan kepada 150 karyawan Hypermart Bandung. Hasil penelitian ini menunjukkan bahwa peran AL pimpinan Hypermart termasuk dalam kategori baik. Demikian pula, OCB pada karyawan termasuk dalam kategori baik. Juga diketahui bahwa AL memiliki pengaruh positif dan signifikan terhadap OCB. Tingkat pengaruh AL terhadap OCB adalah 23,7\%, sedangkan 76,3\% dipengaruhi oleh faktor lain yang tidak dijelaskan dalam penelitian ini.
\end{abstract}

Kata Kunci: kepemimpinan otentik, kepemimpinan, perilaku organisasi, perilaku kewargaan organisasional

\section{PENDAHULUAN}

Sektor ritel di Indonesia terus mengalami pertumbuhan meski sempat

*Email korespondensi:

Rizkita Cahya Henviana

rizkitacahyanina@gmail.com terpengaruh perlambatan ekonomi nasional. Laporan Global Retail Development Index bahkan menunjukkan peringkat Indonesia melonjak ke posisi lima tahun ini dengan nilai penjualan mencapai US\$324 miliar (Margrit dalam industri.bisnis.com, 2016). Berdasarkan Gambar 1, dapat dilihat bahwa 
peringkat Indonesia terus meningkat setiap tahunnya. Peningkatan tajam terjadi pada tahun 2016 dimana Indonesia menduduki peringkat 5 dengan GRDI Score sebesar 55,6. Akan tetapi pada tahun 2017, peringkat Indonesia disusul oleh Turki, Arab Saudi, Vietnam, dan Morocco menjadi peringkat ke-8 dengan GRDI Score yang meningkat sebanyak 0,3 menjadi 55,9. Pencapaian ini masih termasuk sangat baik karena Indonesia berada di top 10 most potentioal retail sectors se-Asia.

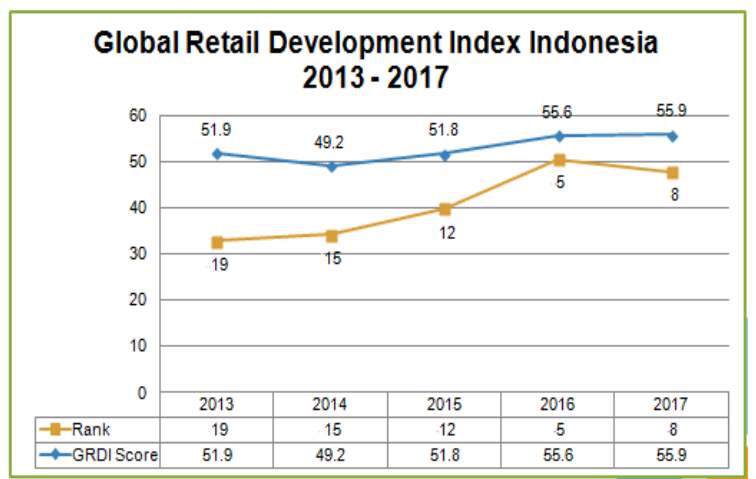

Sumber : www.atkearney.com (2017)

\section{Gambar 1 Grafik Global Retail Development} Index Indonesia 2013-2017

Indonesia merupakan pangsa pasar yang menjanjikan bagi industri ritel karna pertumbuhannya yang meningkat. Pertumbuhan sektor ritel yang terus meningkat disebabkan oleh banyak faktor, salah satunya oleh bertambahnya perusahaan yang bergerak dalam sektor ini. Persaingan ketat antar perusahaan ritel pun tak bisa dihindari. Salah satunya adalah sektor hypermarket. Untuk dapat bertahan dan terus berkembang, perusahaan harus meningkatkan kinerjanya. Salah satu cara yang dapat dilakukan perusahaan untuk meningkatkan kinerja adalah memiliki sumber daya manusia yang kompeten dan loyal dengan kinerja tinggi sehingga dapat meningkatkan efektivitas organisasi.

Kinerja karyawan mempengaruhi pencapaian tujuan organisasi. Dinamika kerja dalam organisasi membutuhkan individu yang efektif dan efisien dalam bekerja, baik secara personal maupun tim.
Terdapat beberapa perilaku individu yang positif untuk menunjang kesuksesan organisasi salah satu yang dibutuhkan adalah kemampuan interpersonal yang tergolong dalam lingkup OCB (Organizational Citizenship Behavior). Menurut Podsakoff, et.al (2000), OCB dapat meningkatkan produktivitas rekan kerja dan produktivitas manager sehingga dapat meningkatkan stabilitas kinerja organisasi.

Menurut Organ et al. (2006) dalam Titisari (2014), peningkatan Organizational Citizenship Behavior (OCB) dipengaruhi oleh dua faktor utama, yaitu; (1) Fakto internal yang berasal dari diri karyawan sendiri, antara lain kepuasan kerja, komitmen, dan kepribadian, moral karywan, motivasi, dan lain sebagainya; (2) Faktor eksternal yang berasal dari luar karyawan, antara lain gaya kepemimpinan, kepercayaan pada pimpinan, budaya organisasi, dan lain sebagainya. Pendapat sejenis juga dikemukakan oleh Wirawan (2013), bahwa terdapat beberapa faktor yang mempengaruhi perilaku kewargaan organisasi, salah satunya adalah kepemimpinan. Kepemimpinan dalam suatu organisasi dirasa sangat penting, karena pemimpin memiliki peranan yang strategis dalam mencapai tujuan organisasi yang biasa tertuang dalam visi dan misi organisasi. Pentingnya aspek sumber daya manusia bagi organisasi, maka peran seorang pemimpin pun tidak kalah pentingnya. Pemimpin berfungsi untuk menggerakkan para pengikut (follower) agar mereka mau mengikuti atau menjalankan apa yang diperintahkan dan dikehendaki pemimpin. Berdasarkan pendapat tersebut, disimpulkan bahwa kepemimpinan menjadi salah satu faktor untuk meningkatkan OCB. Oleh karena itu, penelitian ini meneliti salah satu teori kepemimpinan yaitu Authentic Leadership yang menjadi predictor terhadap OCB.

Pra penelitian telah dilakukan kepada 30 orang karyawan Hypermart BIP melalui pengisian kuesioner. Wawancara juga dilakukan kepada 2 orang manager dan 1 
orang staff. Dari hasil pengisian kuesioner didapat data bahwa pemimpin menunjukan sikap dan sifat dari kepemimpinan otentik. Sebanyak $70 \%$ responden setuju bahwa atasan langsungnya memberikan informasi secara terbuka. Hal ini sesuai dengan salah satu dimensi dari kepemimpinan otentik yaitu relational transparency bahwa pemimpin bersifat terbuka dalam memberikan informasi. Dimensi internalized moral prespective menjadi kelemahan dari perilaku kepemimpinan otentik berdasarkan pernyataan $80 \%$ karyawan yang ragu-ragu bahwa atasan langsungnya menunjukan konsistensi antara keyakinan dan tindakannya. Selain itu, atasan langsung yang menolak tekanan dari pihak lain untuk melakukan hal-hal yang bertentangan dengan keyakinan dirinya juga dinyatakan ragu-ragu oleh $70 \%$ responden.

Berdasarkan kuesioner yang diisi oleh 30 responden mengenai perilaku kewargaan organisasi, sebanyak $80 \%$ responden mau membantu mengorientasi dan membantu melakukan pekerjaan karyawan baru. Selain itu, sebanyak $85 \%$ karyawan selalu berdiskusi dengan rekan kerjanya sebelum bertindak agar tidak merugikan orang lain. Secara umum perilaku kewargaan organisasi yang dilakukan oleh karyawan Hypermart sudah baik dari segi dimensi altruism, consciencetiousness, courtesy, dan sprotmanship. Namun, dimens civic virtue yang diindikasikan dengan perilaku karyawan yang berpartisipasi dalam menghadiri acara yang wajib bagi dirinya masih kurang. Hal ini ditandai dengan 55\% responden yang menyatakan bahwa ia tidak selalu mengikuti acara-acara tidak wajib yang diadakan perusahaan.

Berdasarkan hasil wawancara terhadap 2 manager didapat informasi bahwa sebagai pemimpin, mereka memiliki prinsip kejujuran dan integritas. Hal ini sesuai dengan karakteristik dari pemimpin otentik. Selain itu, para manager berinteraksi aktif dengan karyawan dengan menerima masukan dan saran serta berdiskusi untuk pemecahan masalah. Selanjutnya dari wawancara yang dilakukan terhadap 1 orang staf didapat informasi bahwa karyawan saling membantu rekan nya dalam mengerjakan tugas, hal ini dilakukan karena tuntutan pekerjaannya mengharuskan mereka bekerja sama dalam menyelesaikan tugas. Selain itu didapat informasi bahwa beberapa karyawan jarang mengikuti acara yang diselenggarakan oleh perusahaan yang sifatnya tidak wajib. Informasi dari wawancara ini selaras dengan hasil kuesioner pra penelitian yang diisi oleh 30 responden.

Selain itu didapatkan informasi dari karyawan bahwa penjualan yang dilakukan oleh Hypermart sedang mengalami penurunan. Hal ini didukung oleh pernyataan Danny Kojongian, Sekretaris Perusahaan Matahari Putra Prima, menuturkan laba bersih yang dikantongi perseroan pada 2016 mencapai Rp 38,48 miliar. Nilai tersebut turun $83 \%$ dari laba bersih 2015 yang tercatat sebesar Rp 221,74 miliar (Noviani dalam market.bisnis.com, 2017). Hypermart pun termasuk pada 5 besar perusahaan ritel dengan tingkat shringkage tertinggi. Hal ini tentunya dapat menurunkan kinerja organisasi. Oleh karena itu penerapan kepemimpinan otentik yang dapat meningkatkan perilaku kewargaan organisasional diharapkan dapat mempengaruhi kesuksesan organisasi dari segi pendapatan maupun iklim organisasi yang positif. Peranan kepemimpinan yang otentik diharapkan dapat memberi energi bagi karyawan untuk bekerja semaksimal mungkin dalam rangka meningkatkan kinerja perusahaan.

\section{TINJAUAN TEORITIS}

\section{Kepemimpinan Otentik (Authentic Leadership)}

Kepemimpinan otentik sebenarnya telah dikonseptualisasikan pada akhir tahun 1970 namun penelitian yang lebih mendalam mengenai konsep ini baru dimulai pada awal tahun 2000 (Avolio dan Garner, 2005). Pada tahun 2003 teori 
authentic leadership pertama kali dikembangkan oleh Avolio dan Luthans. Kepemimpinan otentik merupakan salah satu teori kepemimpinan terbaru yang muncul di kalangan akademisi. Kepemimpinan otentik telah diasumsikan sebagai posisi penting antara pendekatan berbasis kekuatan yang telah maju sebagai solusi potensial untuk tantangan kepemimpinan modern (Caza \& Jackson, 2011).

Avolio, Luthans, \& Walumbwa (2004) dalam Garner et.al (2011) mendefinisikan pemimpin otentik sebagai pemimpin yang sangat sadar terhadap dirinya (deeply aware) dalam berpikir dan bertindak, serta dipersepsi orang lain sebagai orang yang sadar terhadap nilai-nilai moral dirinya dan orang lain; berwawasan luas dan memiliki kekuatan; sadar konteks di mana sedang berada; merasa yakin, memiliki harapan, optimisme, ketangguhan, dan karakter moral yang tinggi.

Pemimpin otentik memiliki perilaku konsisten dengan nilai-nilai dan moral, menjunjung tinggi integritas dan kepercayaan di antara pengikut. Mereka selaras dengan kekuatan dan kelemahan mereka serta bagaimana kekuatan dan kelemahan mereka dirasakan oleh orang lain, sehingga mereka dapat sangat efektif menggunakan konsep pengetahuan diri (selfknowledge) untuk mengembangkan dan memimpin. (Walumbwa, Avolio, et al., 2008 dalam Kiersch dan Byrne 2015).

George (2003) mengemukakan bahwa pemimpin otentik menggunakan kemampuan alami mereka, tetapi mereka juga mengakui kekurangan mereka, dan bekerja keras untuk mengatasinya. Mereka memimpin dengan tujuan, makna, dan nilainilai. Mereka membangun hubungan yang berkelanjutan dengan orang-orang. Lainnya mengikuti mereka karena mereka tahu di mana mereka berdiri. Mereka konsisten dan disiplin. Ketika prinsip-prinsip mereka diuji, mereka menolak untuk berkompromi. Pemimpin otentik berdedikasi untuk mengembangkan diri mereka sendiri karena mereka tahu bahwa menjadi seorang pemimpin membutuhkan pengembangan seumur hidup.

Walumbwa et al. (2008) mengidentifikasi empat komponen untuk menjelaskan authentic leadership, antara lain:

1. Self-awareness, menunjukkan pemahaman tentang bagaimana seseorang memperoleh dan membuat tujuan hidupnya dan bagaimana proses pembuatan tujuan ini mempengaruhi cara seseorang memandang dirinya sendiri dari waktu ke waktu. Ini juga mengacu pada menunjukkan pemahaman tentang kekuatan dan kelemahan seseorang dan sifat diri yang beragam, termasuk mendapatkan wawasan tentang diri melalui pandangan terhadap orang lain, dan menyadari dampak perbuatannya terhadap orang lain.

2. Relational Transparency, mengacu pada memperlihatkan dirinya yang sejati kepada orang lain. Perilaku seperti itu mendorong kepercayaan melalui pengungkapan yang melibatkan keterbukaan informasi. ungkapan pikiran dan perasaan seseorang saat mencoba meminimalkan tampilan emosi yang tidak tepat.

3. Balanced Processing, mengacu pada pemimpin yang menunjukkan bahwa mereka secara objektif menganalisis semua data yang relevan sebelum mengambil keputusan termasuk juga pendapat atau pandangan dari orang yang mungkin bertentangan.

4. Internalized Moral Perspective, aspek ini memberikan fondasi moral untuk Authentic Leadership, pemimpin dalam hal ini mampu menunjukkan kepada orang lain konsistensinya akan nilai atau keyakinan dasar yang dianut dan dapat terlihat melalui tindakan, sikap dan perilaku pemimpin sehari-hari. Lebih lanjut lagi, konsep ini mengacu pada bentuk nilai yang dianut dan diintegrasikan dari pengaturan diri 
Perilaku Kewargaan Organisasional (Organizational Citizenship Behavior OCB)

Organizational Citizenship Behavior

(OCB) atau perilaku kewargaan organisasi merupakan salah satu outcome variable dari perilaku organisasi dan merupakan bagian dari perilaku organisasi yang positif. Pada tahun 1980-an, (OCB) dikategorikan ke dalam "Perilaku Ekstra-Peran" yang diusulkan pertama kali oleh Katz pada tahun 1964. Perilaku tersebut menjadi awal mula pengembangan teori organizational citizenship behavior oleh Bateman dan Organ pada tahun 1983 (Sepeng, 2016). Organ (1998) dalam Al Sahi Al Zaabi et. al, (2016) mengemukakan bahwa OCB meliputi perilaku informal dan sukarela karyawan terhadap organisasi dan rekan-rekan mereka, yang mengarah kepada pertumbuhan organisasi. Selanjutnya, OCB berkonsentrasi pada kontribusi karyawan yang melampaui harapan; dengan kata lain, OCB adalah perilaku ekstra-peran karyawan dalam bekerja yang memberikan kontribusi untuk keberhasilan organisasi (Podsakoff \& Mackenzie, 1994 dalam Al Sahi Al Zaabi et. al, 2016).

Organ (1988) dalam Wherry (2012) menyatakan bahwa "Organizational Citizenship Behavior as individual behaviour that is discretionary, not directly or explicitly recognized by the formal reward system, and in the aggregate promotes the efficient and effective functioning of the organization" yang berarti bahwa OCB adalah bentuk perilaku yang merupakan pilihan dan inisiatif individual, tidak berkaitan dengan sistem reward formal organisasi tetapi secara keseluruhan dapat meningkatkan efisiensi dan efektivitas organisasi.

Greenberg (2011:

mendefinisikan Organizational Citizenship Behavior sebagai suatu bentuk perilaku informal seseorang diluar perilaku formal yang diharapkan dari mereka untuk memberikan kontribusi terhadap kebaikan organisasi dan apa yang ada di dalamnya.
Selanjutya Robbins \& Judge (2015: 58) mendefinisikan OCB sebagai perilaku diskresioner yang berkontribusi pada lingkungan psikologis dan sosial tempat kerja. Karyawan yang memiliki perilaku kewargaan yang baik akan membantu rekan dalam tim, sukarela untuk bekerja ekstra, menghindari konflik yang tidak perlu, menghormati peraturan, dan dengan lapang dada mentolerir pemaksaan dan gangguan sesekali yang berhubungan dengan pekerjaan.

Menurut Kreitner dan Kinicki (2014: 173) OCB adalah perilaku pegawai yang melebihi persyaratan peran pekerjaan. Contoh-contohnya adalah sikap sebagai pernyataan konsturktif mengenai departemen, pengungkapan minat pribadi dalam pekerjaan orang lain, saran-saran untuk peningkatan, pelatihan pegawai baru, rasa hormat untuk semangat dan tulisan aturan pemeliharaan bangunang, peduli terhadap properti perusahaan, serta ketepatan waktu dan kehadiran di atas standar atau tingkat yang dapat dilaksanakan.

Organ et. al (1988) dalam Titisari (2014) mengidentifikasi lima dimensi dari OCB, yaitu:

1. Altruism

Perilaku karyawan dalam menolong rekan kerjanya yang mengalami kesulitan dalam situasi yang sedang dihadapi baik mengenai tugas dalam organisasi maupun masalah pribadi orang lain. Dimensi ini mengarah kepada memberi pertolongan yang bukan merupakan kewajiban yang ditanggungnya (sukarela)..

2. Civic Virtue

Perilaku yang mengindikasikan tanggung jawab pada kehidupan organisasi dan tanggung jawab yang diberikan organisasi untuk meningkatkan kualitas bidang pekerjaan yang ditekuni (mengikuti perubahan dalam organisasi, mengambil inisiatif untuk merekomendasikan bagaimana operasi atau prosedur-prosedur 
organisasi dapat diperbaiki, dan melindungi sumber-sumber yang dimiliki oleh organisasi).

3. Conscientiousness

Perilaku yang ditunjukkan dengan berusaha melebihi yang diharapkan perusahaan. Perilaku sukarela yang bukan merupakan kewajiban atau tugas karyawan. Dimensi ini menjangkau jauh di atas dan jauh ke depan dari panggilan tugas.

4. Courtesy

Menjaga hubungan baik dengan rekan kerjanya agar terhindar dari masalahmasalah interpersonal. Seseorang yang memiliki dimensi ini adalah orang yang menghargai perasaan maupun pemikiran serta memerhatikan orang lain.

5. Sportmanship

Perilaku yang memberikan toleransi terhadap keadaan yang kurang ideal dalam organisasi tanpa mengajukan keberatan-keberatan. Seseorang yang mempunyai tingkatan yang tinggi dalam sportsmanship akan meningkatkan iklim yang positif diantara karyawan, karyawan akan lebih sopan dan bekerja sama dengan yang lain sehingga akan menciptakan lingkungan kerja yang menyenangkan.

\section{Hubungan Antara Authentic Leadership dengan Organizational Citizenship Behavior}

Menurut Organ et al. (2006) dalam Titisari (2014), peningkatan Organizational Citizenship Behavior (OCB) dipengaruhi oleh dua faktor utama, yaitu; (1) Fakto internal yang berasal dari diri karyawan sendiri, antara lain kepuasan kerja, komitmen, dan kepribadian, moral karywan, motivasi, dan lain sebagainya; (2) Faktor eksternal yang berasal dari luar karyawan, antara lain gaya kepemimpinan, kepercayaan pada pimpinan, budaya organisasi, dan lain sebagainya. Pendapat sejenis juga dikemukakan oleh Wirawan (2013) bahwa terdapat beberapa faktor yang mempengaruhi perilaku kewargaan organisasi, salah satunya adalah kepemimpinan. Berdasarkan pendapat tersebut, disimpulkan bahwa kepemimpinan menjadi salah satu faktor untuk meningkatkan OCB Oleh karena itu, penelitian ini meneliti salah satu teori kepemimpinan yaitu Authentic Leadership yang menjadi predictor terhadap OCB.

Penelitian sebelumnya yang dilakukan oleh Walumbwa et. al (2010) menemukan bahwa authentic leadership berdampak pada hasil kerja karyawan, seperti organizational citizenship behavior (OCB), komitmen, dan keterperikatan. Ketika karyawan lebih terlibat di tempat kerja mereka, mereka menunjukkan tingkat OCB yang tinggi, yang meningkatkan keseluruhan efisiensi, efektivitas, dan kinerja organisasi. (Organ dalam Al Sahi Al Zaabi et. al, 2016). Tingkat OCB yang tinggi menjadikan karwayan tidak hanya bekerja sesuai tugas pokok saja, keterlibatan karyawan menunjukkan usaha lebih dalam kegiatan yang melampaui tugas pokok mereka.

Selanjutnya, studi dilakukan kembali oleh Walumbwa et al. (2010), dan memperoleh hasil hubungan positif antara kepemimpinan otentik dan perilaku kewargaan organisasional karyawan. Studi mengungkapkan bahwa terdapat hubungan positif antara dua variabel baik pada individu dan kelompok. Pemimpin yang dianggap lebih otentik berpengaruh dalam memfasilitasi helping behavior karyawan dengan membuat karyawan lebih sadar akan pentingnya membantu satu sama lain.

Berdasarkan penelitian para cendekiawan terdahulu, dapat disimpulkan bahwa authentic leadership berpengaruh terhadap organizational citizenship behavior. Peneliti terdahulu ini pun menjadi landasan bagi para peneliti yang baru-baru ini mengkaji mengenai hubungan $\mathrm{AL}$ dan OCB yaitu; Al Sahi Al Zabi, et.al (2016), Joo \& Jun Jo (2017), Cotrill, et.al (2014) dan Tonkin (2014) yang semuanya menunjukkan hubungan positif antara 
authentic leadership dan organizational citizenship behavior.

\section{Hipotesis}

Ho : Kepemimpinan otentik tidak berpengaruh positif dan signifikasn terhadap perilaku kewargaan organisasional.

$\mathrm{Ha}$ : Kepemimpinan otentik tidak berpengaruh positif dan signifikasn terhadap perilaku kewargaan organisasional

\section{METODE PENELITIAN}

Metode penelitian yang digunakan adalah metode penelitian kuantitatif. Penelitian ini menggunakan dua jenis data, yaitu data sekunder dan data primer yang diperoleh secara langsung dari responden, menggunakan kuesioner yang valid dan reliabel dengan nilai cronbach's alpha yaitu 0,844 untuk AL dan 0,732 untuk OCB. Kuesioner di dalam penelitian ini terdiri dari 33 pernyataan tertutup yang diadaptasi dari Authentic Leadership Inventory (ALI) yang dikembangkan oleh Neider dan Schriesheim (2011) dan alat ukur OCB yang dikembangkan oleh Podsakoff et, al (1990) dalam Wiranegara (2013).

Populasi penelitian ini adalah karyawan Hypermart yang tersebar di kota Bandung yaitu di MTC, BIP, dan Miko Mall yang berjumlah 240 karyawan. Jumlah sampel dipilih menggunakan rumus Slovin dengan tingkat kesalahan 5\% sehingga didapat sampel dalam penelitian ini berjumlah 150 karyawan. Metode pengambilan sampel yang digunakan adalah metode probability sampling dan teknik pengambilan sampel yang digunakan adalah simple random sampling. Analisis data dalam penelitian ini menggunakan analisis deskriptif, analisis korelasi, regresi linier sederhana, koefisien determinasi dan uji hipotesis menggunakan uji statistik $\mathrm{F}$ dan uji statistik t.

\section{HASIL DAN PEMBAHASAN}

Analisis Deskriptif Authentic Leadership

Analisis deskriptif ini dilakukan

untuk mengukur presepsi karyawan mengenai penerapan Authentic Leadership di Hypermart Bandung. Dari hasil pengolahan data statistik yang terlihat pada Tabel 1, diketahui bahwa variabel authentic leadership memiliki nilai rata-rata sebesar 3,55 dan termasuk dalam kategori baik. Rata-rata seluruh dimensi pun berada dalam kagori baik. Hal ini menandakan bahwa para pemimpin Hypermart Bandung sudah memiliki self awareness, relational transparency, internalized moral prespective dan balanced processing dalam menerapkan authentic leadership menurut presepsi karyawan (bawahannya).

Tabel 1. Statistik Deskriptif Variabel AL

\begin{tabular}{|l|r|r|r|r|r|}
\hline & $\mathrm{N}$ & Min & Max & Mean & $\begin{array}{c}\text { Std. } \\
\text { Deviation }\end{array}$ \\
\hline $\begin{array}{l}\text { Dimensi Self } \\
\text { Awareness }\end{array}$ & 150 & 1 & 5 & 3.53 & .668 \\
\hline $\begin{array}{l}\text { Dimensi Relational } \\
\text { Transparency }\end{array}$ & 150 & 1 & 5 & 3.66 & .620 \\
\hline $\begin{array}{l}\text { Dimensi Internalized } \\
\text { Moral Perspective }\end{array}$ & 150 & 1 & 5 & 3.43 & .598 \\
\hline $\begin{array}{l}\text { Dimensi Balanced } \\
\text { Processing }\end{array}$ & 150 & 1 & 5 & 3.58 & .608 \\
\hline $\begin{array}{l}\text { Authentic } \\
\text { Leadership }\end{array}$ & $\mathbf{1 5 0}$ & $\mathbf{1}$ & $\mathbf{5}$ & $\mathbf{3 . 5 5}$ & $\mathbf{. 4 8 0}$ \\
\hline Valid N (listwise) & 150 & & & & \\
\hline
\end{tabular}

Dari empat dimensi yang menentukan authentic leadership, dimensi relational transparency memiliki nilai mean tertinggi yaitu sebesar 3,66. Menurut Walumbwa et al. (2008) self-awareness mengacu pada sikap pemimpin yang memberikan kesempatan kepada pengikutnya untuk memberikan masukan atau feedback berupa ide, tantangan ataupun opini.

Dimensi dengan nilai mean terendah adalah dimensi internalized moral prespective yaitu sebesar 3,43. Menurut Walumbwa et al. (2008) internalized moral pespective mengacu pada sikap pemimpin yang mampu menunjukkan kepada orang lain konsistensinya akan nilai atau keyakinan dasar yang dianut dan dapat 
terlihat melalui tindakan, sikap dan perilaku pemimpin sehari-hari.

\section{Analisis Deskriptif Organizational Citizenship Behavior}

Dari hasil pengolahan data statistik yang terlihat pada Tabel 2, diketahui bahwa variabel OCB memiliki nilai rata-rata sebesar 3,74 dan termasuk dalam kategori baik. Rata-rata seluruh dimensi pun berada dalam kagori baik. Hal ini menandakan bahwa karyawan Hypermart Bandung sudah memiliki altruism, conscientiousness, sportsmanship, courtesy, dan civic virtue dalam menerapkan organizational citizenship behavior di lingkungan kerja.

Tabel 2. Statistik Deskriptif Variabel OCB

\begin{tabular}{|l|r|r|r|r|r|}
\hline & $\mathrm{N}$ & Min & Max & Mean & $\begin{array}{c}\text { Std. } \\
\text { Deviation }\end{array}$ \\
\hline Altruism & 150 & 2 & 5 & 3.78 & .653 \\
\hline Conscientiousness & 150 & 2 & 5 & 3.69 & .440 \\
\hline Sportmanship & 150 & 2 & 5 & 3.72 & .473 \\
\hline Courtesy & 150 & 2 & 5 & 3.96 & .478 \\
\hline CivicVirtue & 150 & 1 & 5 & 3.55 & .558 \\
\hline OCB & $\mathbf{1 5 0}$ & $\mathbf{1}$ & $\mathbf{5}$ & $\mathbf{3 . 7 4}$ & $\mathbf{. 3 3 6}$ \\
\hline $\begin{array}{l}\text { Valid N } \\
\text { (listwise) }\end{array}$ & 150 & & & & \\
\hline
\end{tabular}

Sumber : Olah Data SPSS (2017)

Dari lima dimensi yang menentukan OCB, dimensi civic virtue memiliki nilai mean terendah yaitu sebesar 3,55. Menurut Organ et. al (1988) dalam Podsakoff et. al (2000), dimensi ini diindikasikan dengan perilaku karyawan yang berpartisipasi sukarela untuk fungsi-fungsi organisasi sekalipun tidak diwajibkan, tetapi dapat menciptakan citra baik bagi organisasi. Sedangkan dimensi dengan nilai mean tertinggi adalah dimensi courtesy yaitu sebesar 3,96. Dimensi ini diindikasikan dengan perilaku karyawan yang mencegah terjadinya konflik dan memahami dampak dari tindakannya terhadap rekan kerja (Organ et. al, 1988 dalam Podsakoff et. al, 2000).

Dimensi

conscientiousness, dan altruism, sportsmanship memiliki mean yang tidak jauh berbeda yaitu masing-masing sebesar 3,78; 3,63; dan 3,72. Altruism diindikasikan dengan perilaku karyawan yang membantu pekerjaan rekan kerja yang absen, overload, mengorientasi karyawan baru, dsb. Conscientiousness diindikasikan dengan kepatuhan terhadap aturan, tingkat kehadiran yang tinggi, dsb. Sportsmanship diindikasikan dengan kemauan untuk bertoleransi tanpa mengeluh, tidak membesar-besarkan masalah, dsb (Organ et. al, 1988 dalam Podsakoff et. al, 2000).

\section{Hasil Analisis Korelasi}

Berdasarkan Tabel 3, dapat dilihat nilai korelasi antara variabel authentic leadership dan organizational citizenship behavior yaitu sebesar 0,487. Jika mengacu pada interpretasi nilai hasil analisis korelasi menurut Bungin (2010:184), nilai korelasi sebesar 0,487 artinya terdapat hubungan positif yang sedang (moderate). Nilai korelasi pearson pada Tabel 3 menunjukan nilai yang positif, maka hubungan antara variabel AL dan OCB searah, yang artinya jika authentic leadership meningkat maka akan diikuti oleh peningkatan OCB pula.

Tabel 3. Hasil Uji Korelasi

\begin{tabular}{|l|l|r|r|}
\hline & & TOTAL_AL & TOTAL_OCB \\
\hline \multirow{3}{*}{$\begin{array}{l}\text { Authentic } \\
\text { Leadership }\end{array}$} & $\begin{array}{l}\text { Pearson } \\
\text { Correlation }\end{array}$ & 1 & $.487^{* *}$ \\
\cline { 2 - 4 } & Sig. (2-tailed) & & .000 \\
\cline { 2 - 4 } & $\mathrm{N}$ & 150 & 150 \\
\hline $\begin{array}{l}\text { Organizational } \\
\text { Citizenship } \\
\text { Behavior }\end{array}$ & Pearson & $.487^{* *}$ & 1 \\
\cline { 2 - 4 } & Correlation & & \\
\cline { 2 - 4 } & Sig. (2-tailed) & .000 & \\
\cline { 2 - 4 } & $\mathrm{N}$ & 150 & \\
\hline
\end{tabular}

Sumber : Olah Data SPSS (2017)

\section{Hasil Uji Regresi Linier Sederhana}

Tabel 4 digunakan untuk menggambarkan perumusan regresi untuk mengetahui pengaruh authentic leadership terhadap OCB. Berdasrkan Tabel 4 tersebut, diperoleh bahwa nilai konstanta (a) sebesar 43,150 dan nilai koefisien regresi (b) sebesar 
0,358. Maka dari itu, diperoleh persamaan regresi sebagai berikut:

$$
\begin{array}{|c|}
\hline \mathbf{Y}=\mathbf{a}+\mathbf{b X} \\
\mathbf{Y}=43,150+0,358 \mathbf{X}
\end{array}
$$

Dari persamaan regresi linier sederhana di atas, nilai konstanta (a) sebesar 43,150; ini dapat diartikan jika authentic leadership bernilai $(\mathrm{X}=0)$, maka OCB yang tercapai sebesar 43,150. Nilai koefisien regresi (b) bernilai positif sebesar 0,358 ; ini dapat diartikan bahwa setiap peningkatan authentic leadership sebesar satu angka, maka OCB akan meningkat sebesar 0,358.

Tabel 4. Hasil Analisis Regresi Linier Sederhana

\begin{tabular}{|l|l|r|r|r|r|r|}
\hline \multirow{2}{*}{ Model } & \multicolumn{2}{|c|}{$\begin{array}{c}\text { Unstandardized } \\
\text { Coefficients }\end{array}$} & $\begin{array}{c}\text { Standardized } \\
\text { Coefficients }\end{array}$ & \multirow{2}{*}{ t } & \multirow{2}{*}{ Sig. } \\
\cline { 2 - 6 } & B & $\begin{array}{c}\text { Std. } \\
\text { Error }\end{array}$ & \multicolumn{1}{|c|}{ Beta } & & \\
\hline 1 & (Constant) & 43.150 & 3.025 & & 14.263 & .000 \\
\cline { 2 - 5 } & $\begin{array}{l}\text { Kepemimpinan } \\
\text { Otentik }\end{array}$ & .358 & .053 & .487 & 6.785 & .000 \\
\hline
\end{tabular}

a. Dependent Variable: Perilaku Kewargaan Organisasional Sumber : Olah Data SPSS (2017)

\section{Hasil Koefisien Determinasi}

Berdasarkan tabel 5, diketahui nilai dari koefisien determinasi ( $\mathrm{R}$ Square/ $\mathrm{R}^{2}$ ) sebesar 0,237. Artinya, bahwa AL mampu mempengaruhi OCB sebanyak 23,7\%, sedangkan sisanya sebesar 76,3\% dijelaskan oleh faktor-faktor lain yang tidak diteliti dalam penelitian ini.

Tabel 5. Hasil Koefisien Determinasi

\begin{tabular}{|l|r|r|r|r|r|}
\hline Model & \multicolumn{1}{|c|}{$\mathrm{R}$} & $\begin{array}{c}\mathrm{R} \\
\text { Square }\end{array}$ & $\begin{array}{r}\text { Adjusted } \\
\text { R Square }\end{array}$ & $\begin{array}{c}\text { Std. Error } \\
\text { of the } \\
\text { Estimate }\end{array}$ & $\begin{array}{l}\text { Durbin- } \\
\text { Watson }\end{array}$ \\
\hline 1 & $.487^{\mathrm{a}}$ & .237 & .232 & 4.956 & 1.691 \\
\hline
\end{tabular}

a. Predictors: (Constant), Kepemimpinan Otentik

b. Dependent Variable: Perilaku Kewargaan Organisasional

Pengaruh Authentic Leadership terhadap Organizational Citizenship Behavior

Berdasarkan hasil pengolahan data, diketahui bahwa terdapat hubungan antara authentic leadership dan organizational citizenship behavior. Hal ini didapatkan dari hasil analisis korelasi antara variabel AL dan OCB yaitu sebesar 0,487 yang termasuk dalam hubungan positif yang kuat.

Kemudian berdasarkan hasil regresi linier sedehana, didapatkan persamaan $\mathrm{Y}=$ $43,150+0,358 X$. diketahui nilai konstanta sebesar 43,150 dan koefisien regresi bernilai positif sebesar 0,358; ini dapat diartikan bahwa setiap peningkatan authentic leadership sebesar satu angka, maka OCB akan meningkat sebesar 0,358.

Selanjutnya berdasarkan hasil koefisien determinasi, AL mampu mempengaruhi OCB sebanyak 23,7\%, sedangkan sisanya sebesar $76,3 \%$ dijelaskan oleh faktor-faktor lain yang tidak diteliti dalam penelitian ini.

Uji hipotesis digunakan untuk mengetahui apakah authentic leadership berpengaruh signifikan terhadap organizational citizenship behavior. Uji hipotesis yang dilakukan dalam penelitian ini adalah uji signifikansi simultan (uji F) dan uji perbedaan (uji T). Tabel 6 dan 7 menyajikan data hasil uji statistik $F$ dan uji statistik t.

Tabel 6. Hasil Uji Statistik F

\begin{tabular}{|l|l|c|c|c|c|c|}
\hline \multicolumn{2}{|l|}{} & $\begin{array}{c}\text { Sum of } \\
\text { Squares }\end{array}$ & df & $\begin{array}{c}\text { Mean } \\
\text { Square }\end{array}$ & F & Sig. \\
\hline \multirow{2}{*}{1} & Regression & 1130.620 & 1 & 1130.620 & 46.035 & $.000^{\mathrm{a}}$ \\
\cline { 2 - 8 } & Residual & 3634.873 & 148 & 24.560 & & \\
\cline { 2 - 8 } & Total & 4765.493 & 149 & & & \\
\hline
\end{tabular}

a. Predictors: (Constant), Kepemimpinan Otentik

b. Dependent Variable: Perilaku Kewargaan

Organisasional

Sumber : Olah Data SPSS (2017)

Berdasarkan uji statistik $F$ pada Tabel 6, dapat dilihat bahwa angka significant pada kolom Sig, adalah 0,000. Nilai tersebut lebih kecil dibandingkan dengan nilai probabilitasnya yang nilainya sebesar 0,05 (5\%). Selanjutnya, nilai $F$ hitung yang didapat yaitu sebesar 46,035, dimana $\mathrm{F}$ tabel sebesar 3,91 yang berarti bahwa nilai $\mathrm{F} 0 \geq \mathrm{F} 1$ yaitu $46,035 \geq 3,91$. Mengacu pada interpretasi hasil uji statistik 
F menurut Arikunto (2010: 268), jika kriteria F0 $\geq F 1$ dengan taraf signifikansi 5\% maka interpretasinya adalah Ho ditolak dan Ha diterima. Hal tersebut menunjukkan bahwa authentic leadership berpengaruh signifikan terhadap organizational citizenship behavior.

Tabel 7. Hasil Uji Statistik T

\begin{tabular}{|l|l|r|r|r|r|r|}
\hline \multirow{2}{*}{ Model } & \multicolumn{2}{|c|}{$\begin{array}{c}\text { Unstandardized } \\
\text { Coefficients }\end{array}$} & $\begin{array}{c}\text { Standardized } \\
\text { Coefficients }\end{array}$ & \multirow{2}{*}{$\mathrm{t}$} & \multirow{2}{*}{ Sig. } \\
\cline { 2 - 6 } & $\mathrm{B}$ & $\begin{array}{c}\text { Std. } \\
\text { Error }\end{array}$ & Beta & & \\
\hline 1 & (Constant) & 43.150 & 3.025 & & 14.263 & .000 \\
\cline { 2 - 5 } & $\begin{array}{l}\text { Kepemimpinan } \\
\text { Otentik }\end{array}$ & .358 & .053 & .487 & 6.785 & .000 \\
\hline
\end{tabular}

a. Dependent Variable: Perilaku Kewargaan Organisasional

Sumber : Olah Data SPSS (2017)

Selanjutnya berdasarkan uji statistik $\mathrm{t}$ pada Tabel 7, diperoleh $\mathrm{t}$ hitung sebesar 6,785. Dimana $t$ tabel sebesar 1.97601. Berdasarkan data tersebut, diperoleh nilai $t$ hitung yang lebih besar dari t tabel $(6,785>$ 1.97601). Angka signifikansi pada kolom Sig. adalah 0,000 , nilai tersebut lebih kecil dibandingkan dengan nilai probabilitasnya yang nilainya sebesar 0,05 atau $5 \%(0,05>$ 0,000). Maka dari itu, mengacu pada pendapat Priyatno (2013:114) yang menyatakan bahwa jika kriteria $\mathrm{t}$ hitung $>\mathrm{t}$ tabel dan tingkat dignifikansi $<0,05$, maka interpretasinya adalah Ho ditolak dan $\mathrm{Ha}$ diterima. Hal tersebut menunjukkan authentic leadership berpengaruh signifikan terhadap organizational citizenship behavior.

\section{KESIMPULAN DAN SARAN \\ Kesimpulan}

1. Peranan authentic leadership dari para atasan di Hypermart termasuk dalam kategori baik. Seluruh dimensi (selfawareness, balanced processing, internalized moral prespective, dan relational transparency) termasuk dalam kategori baik. Namun, dimensi dengan nilai mean tertinggi adalah dimensi relational transparency dan yang terendah adalah dimensi internalized moral prespective.

2. Organizational citizenship behavior pada karyawan di Hypermart bandung termasuk dalam kategori baik. Seluruh dimensi termasuk dalam kategori baik. Namun, dimensi dengan nilai mean tertinggi adalah dimensi courtesy dan yang terendah adalah dimensi civic virtue.

3. Besarnya pengaruh Authentic Leadership terhadap Organizational Citizenship Behavior sebesar 23,7\%, sedangkan $76,3 \%$ dipengaruhi oleh faktor lain yang tidak dijelaskan pada penelitian ini, yaitu kepribadia, budaya organisasi, kepuasan kerja, komitmen organisasi, keadilan organisasi, dan lain sebagainya.

\section{Saran}

1. Menambahkan kriteria dan karakteristik yang termasuk didalam authentic leadership dalam proses seleksi karyawan hingga proses promosi jabatan dengan menggunakan instrumen berupa formulir wawancara untuk meningkatkan authentic leadership.

2. Untuk meningkatkan OCB, diperlukan pemahaman akan pentingnya OCB yang dapat diusahakan dengan memasang poster-poster di sekitar kantor. Untuk dapat meningkatkan perilaku conscientiousness berkaitan dengan melalukan pekerjaan tambahan tanpa imbalan, pemimpin dapat menunjukkan apresiasi terhadap kemunculan OCB dengan memberi pujian secara personal maupun didepan umum. Membuat program "Employee of The Month" untuk karyawan yang menunjukkan OCB dengan memajang foto karyawan yang selanjutnya dapat memberikan nilai tambah terhadap penilaian kinerja karyawan. Pemimpin juga dapat membangun rasa kebersamaan dikantor untuk meningkatkan civic virtue berkaitan dengan partisipasi aktif dalam kegiatan perusahaan dari mulai rapat 
hingga gathering dengan cara mempererat kekompakan antar karyawan di setiap departemen melalui kegiatan diluar kerja yang dilakukan bersama (makan bersama saat jam istirahat, memiliki group chat di sosial media untuk berbagi informasi mengenai pekerjaan dan diluar pekerjaan, dan sebagainya) sehingga terbentuk kenyamanan dan rasa antusias karyawan untuk berpartisipasi aktif dalam kegiatan organisasi.

3. Sebagai pemimpin juga harus menerapkan OCB. Sehingga seiring dengan ditingkatkannya peran authentic leadership dan OCB pada atasan, akan dapat memberikan inisiatif kepada karyawan untuk mendorong OCB dengan menjadikan pemimpinnya sebagai role model.

4. Untuk penelitian selanjunya diharapkan dapat menggunakan variabel bebas lainnya yang termasuk dalam faktorfaktor yang mempengaruhi OCB seperti budaya organisasi, kepuasan kerja, kepercayaan kepada pemimpin, moral karyawan, kepribadian karyawan, dan lain sebagainya, sehingga akan didapat penelitian dan informasi lebih banyak dan bervariasi akan faktor-faktor yang dapat mempengaruhi organizational citizenship behavior.

\section{DAFTAR PUSTAKA}

Administrator. (2017). The 2017 Global Retail Development Index. Diakses 1 Juni, 2017, melalui ATKearney: https://www.atkearney.com/consumerproducts-retail/global-retaildevelopment-index/2017

Administrator. (2017). Top Brand Award. Diakses 1 Juni, 2017, melalui Top Brand Award: award.com/\# http://www.topbrand-

Al Sahi Al Zaabi, M. S., Ahmad, K. Z., \& Hossan, C. (2016). Authentic leadership, work engagement and organizational citizenship behaviors in petroleum company. International Journal of Productivity and Performance Management, 811-830.

Arikunto, S. (2010). Prosedur Penelitian: Suatu Pendekatan Praktik. Jakarta: Rineka Cipta.

Avolio, B., \& Gardner, W. L. (2005). Authentic leadership development: Getting to the root of positive forms of leadership. The leadership quarterly 16 , 315-338.

Bishop, W. H. (2013). Defining the Authenticity in Authentic Leadership. The Journal of Values-Based Leadership, 6(1), 1-8.

Bungin, B. (2010). Metode Penelitian Kuantitatif. Jakarta: Kencana Prenada Media Group.

Caza, A., \& Jackson, B. (2011). Authentic Leadership. In A. Bryman, D. Collinson, K. Grint, B. Jackson, \& M. Uhl-Bien, The Sage Handbook of Leadership (pp. 352-363). London: Sage Publication Ltd.

Cottrill, K., Lopez, P. D., \& Hoffman, C. C. (2014). How authentic leadership and inclusion benefit organizations. Equality, Diversity and Inclusion: An International Journal, 33(3), 275-292.

Gardner, W. L., Coglister, C. C., Davis, K. M., \& Dickens, M. P. (2011). Authentic Leadership: A review of the literature and research agenda. The Leadership Quarterly, 1120-1145.

George, B. (2003). Authentic Leadership: rediscovering the secrets to creating lasting value. San Francisco: JosseyBass.

Greenberg, J. (2011). Behavior in Organization (10th ed.). New Jersey: Pearson Education.

Hughes, R. L., Ginnet, R. C., \& Curphy, G. J., (2002) Leadership: Enhacing the lesson of experience $4^{\text {th }}$ Edition. McGraw-Hill

Joo, B. K., \& Jo, S. J. (2017). The effect of perceived authentic leadership and core self-evaluations on organizational citizenship behavior: the role of psycological empowerment as a partial 
mediator. Leadership \& Organization Development Journal, 36(3), --.

Julianto, P. A. (2016, Desember 28). Aprindo: Industri Ritel Tumbuh Sekitar 10 Persen pada 2016. Diakses 15 Mei, 2017, melalui Industri Bisnis: http://bisniskeuangan.kompas.com/read/ 2016/12/28/172204826/aprindo.industri. ritel.tumbuh.sekitar.10.persen.pada.2016

Kiersch, C. E., \& Byrne, Z. S. (2015). Is Being Authentic Being Fair? Multilevel Examination of Authentic Leadership, Justice, and Employee Outcomes. Jurnal of Leadership \& Organizational Studies, 22, 292-303.

Kreitner, R., \& Kinicki A. (2014). Perilaku Organisasi. Jakarta: Salemba Empat

Luthans, F. (2010). Organizational Behavior Twelfth (12th) Edition. New York: McGraw-Hill.

Margrit, A. (2016, Juni 6). Ritel Indonesia Tumbuh, Angka Penjualan Capai US\$324 miliar. Diakses 15 Mei, 2017, melalui Industri Bisnis: http://industri.bisnis.com/read/20160606 /100/555024/javascript

Neider, L. L., \& Schriesheim, C. A. (2011). The Authentic Leadership Inventory (ALI): Development and empirical tests. Leadership Quarterly, 22(6), 1146-1164

Noviani, A. (2017, April 26). Laba Bersih Melorot, MPPA Absen Bagikan Dividen. Diakses 1 Juni, 2017, melalui Market Bisnis:

http://market.bisnis.com/read/20170426/ 192/648384/laba-bersih-melorot-mppaabsen-bagikan-dividen

Podsakoff, P.M., MacKenzie, S.B., Paine, J.B., \& Bachrach, D. G. (2000). Organizational Citizenship Behaviorus : A critical review of the theoretical and empirical literature and suggestion for future research. Journal of Managemenr, 26(3), 513-563.

Priyatno, D. (2013). Mandiri Belajar Analisis Data dengan SPSS. Yogyakarta: Mediakom.
Robbins, S. P., \& Judge, T. A. (2015). Organizational Behavior (16th ed.). England: Pearson Education.

Sepeng, W. N. (2016). Authentic Leadership, Organizational Citizenship Behaviour and Intention to Leave: The Role of Psychological Capital. Mini dissertation, Vanderbijlpark: North-West University

Titisari, P. (2014). Peranan Organizational Citizenship Behavior (OCB) Dalam Meningkatkan Kinerja Karyawan. Jakarta: Mitra Wacana Media

Tonkin, T. H. (2013). Authentic Versus Transformational Leadership: Assessing Their Effectiveness on Organizational Citizenship Behavior of Followers. International Journal of Business and Public Administration, 10, 40-55.

Walumbwa, F. O., Avolio, B. J., Gardner, W. L., Wernsing, T. S., \& Peterson, S. J. (2008). Authentic leadership: Development and validation of a theorybased measure. Journal of Management,34, 89-126.

Walumbwa, F. O., Wang, P., Wang, H., Schaubroeck, J., \& Avolio, B. J. (2010). Psychological processes linking authentic leadership to follower behaviors. Leadership Quarterly, 21, 901-914.

Wherry, H. M. S. (2012). Authentic Leadership, Leader-Member Exchange, And Organizational Citizenship Behavior: A Multilevel Analysis. A Dissertation. Presented to The Faculty of the Graduate College at The University of Nebraska. Lincoln, Nebraska

Wiranegara, G. M. (2013). Hubungan Gaya Kepemimpinan Transformasional dan Perilaku Kewargaan Organisasi serta Peningkatan Pengetahuan Gaya Kepemimpinan Transformasional Melalui Pelatihan Kepada Atasan di PT. $\mathrm{X}$. Thesis, Depok: Universitas Indoneisa Wirawan. (2013). Kepemimpinan: Teori, Psikologi, Perilaku Organisasi, Aplikasi dan Penelitian. Jakarta: Rajawali Pers. 